\title{
¿Mares o Mareas?
}

Por Zaira Imelda León Salguero

Estudiante del VIII semestre de la Licenciatura en Artes Plásticas zaira.leonsa@gmail.com

Antes Marea, ahora, en el 2018, Mares de Arena, una obra presentada en el Foro de Bellas Artes de la Universidad de Sonora, donde por fuera, poco antes de las 19:00 horas, hora a la que comenzaría la puesta en escena, se entremezclaban voces, risas y ademanes en los pasillos y patios del área, siempre llena de energía, que se reflejaría en el escenario. Era 21 de febrero, el primero de los tres días que duraría la temporada. No sabía que esperar, simplemente quería ver. Tercera llamada, quedó todo a oscuras.

El evento comenzó con un leve sonido. La iluminación se hizo presente, dejaba ver una quietud de formas que yacían de costado sobre el suelo del escenario, tantos pares de pies desnudos como cuerpos vestidos entre mínimos movimientos. Entonces me relajé, como en un proceso de hipnosis, donde la tranquilidad envuelve y repentinamente, atrapa.

Tan pronto como la música y dinamismo fueron en aumento, el ritmo y la tensión aparecieron. Figuras inquietas, en varias direcciones, realizaban movimientos continuos, enérgicos, pero también sutiles. Sin advertirlo, toda mi atención; mirada-emoción, estaba convertida en una especie de atmósfera, distribuida por todo el escenario, metiéndose entre los personajes, desplazándose con ellos, separándose en espacios para envolver un dueto o escapar cómplice tras un impulso o ante un giro.

Sobre el vaivén de los ritmos y las exaltaciones, mi vista fluía a la par, pero a la vez, huía de aquellos pasos espontáneos, para no obstruir a este conjunto o al que se alzaba más allá y rodando conducía mis ojos por el escenario. Me dejé llevar por la coreografía, percibiendo bajo un haz, la lluvia junto a la música, que en algún momento me hizo pensar en "el lado oscuro de la Luna", que apareció proyectada al fondo, por la cara iluminada, completamente llena, como pupila testigo, control y descontrol de los mares.

Pronto luces cálidas secaron los cuerpos, y me encontré ante un desierto poblado de insectos, recreando su voz a través de sonidos y el movimiento de sus piernas. 


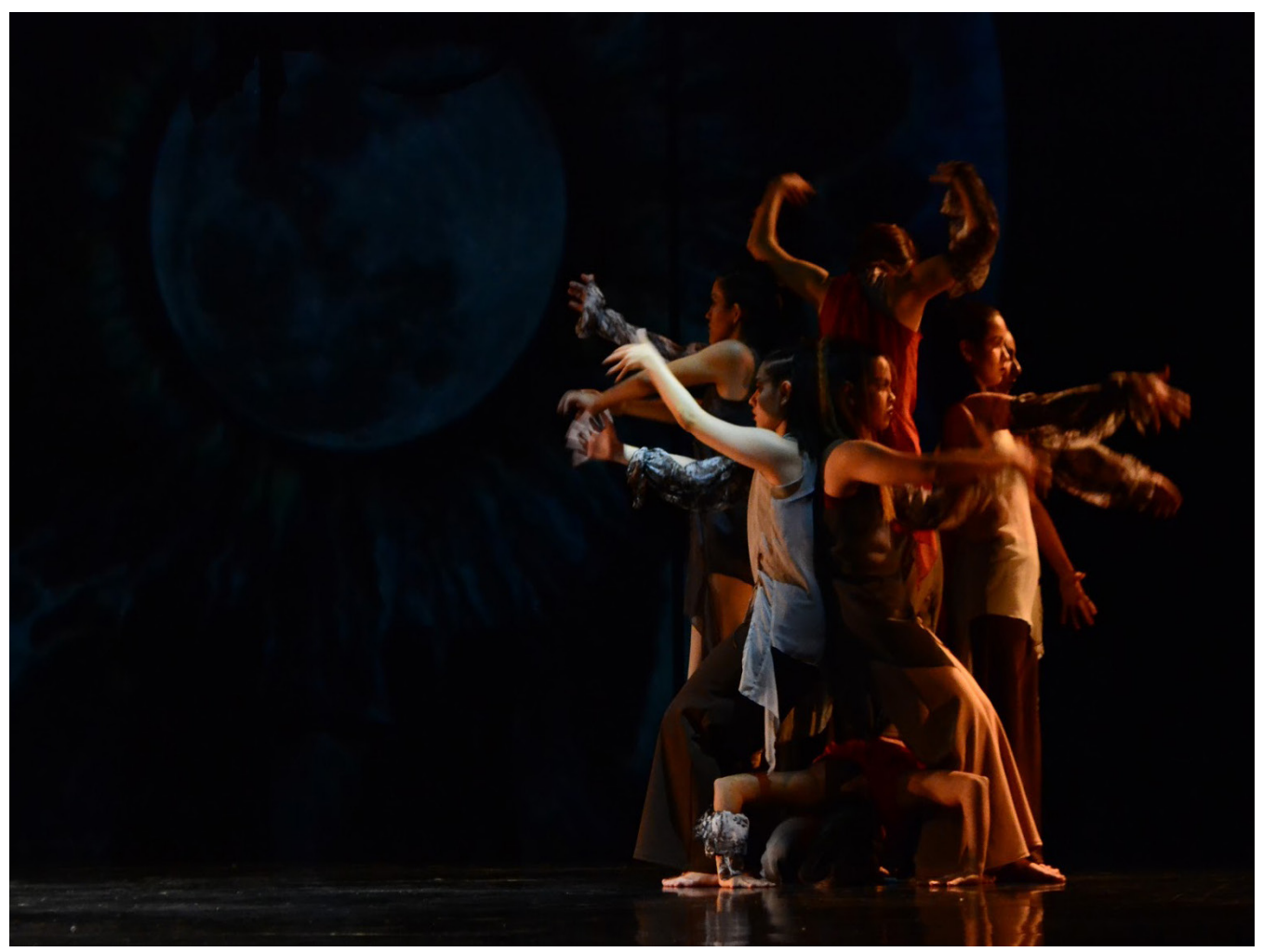

Fotografía Zaira León

La luz azul, cual agua, se mezclaba con los vestuarios colores tierra, al agitarse las dinámicas anatomías, que en desenlace hicieron su danza, como arena bailando al ritmo de Mareas en un contraste musical.

Llegaron los aplausos, los alumnos ejecutantes, con gusto los recibieron y al salir del foro sus caras aún sonreían, con destellos en el rostro a razón del maquillaje, y en los ojos quizá por la emoción del resultado. El trabajo creativo, fue desarrollado dentro de la clase de Laboratorio II a cargo del Maestro David Barrón, en la Licenciatura de Artes Escénicas opción Danza. 